\title{
Terapi Oksigen Hiperbarik Meningkatkan Kualitas Hidup Pasien Glioblastoma Multiforme Stadium Akhir Dinilai Berdasarkan Neurologic Assessment Neuro Oncology Score
}

\author{
Hanni Djunadi, ${ }^{1}$ Maximillian Ch. Oley, ${ }^{2,3}$ Eko Prasetyo, ${ }^{2,3}$ Mendy Hatibie, ${ }^{4,5}$ Fredrik G. \\ Langi ${ }^{6}$
}

\author{
${ }^{1}$ Program Pendidikan Dokter Spesialis Fakultas Kedokteran Universitas Sam Ratulangi, \\ Manado, Indonesia \\ ${ }^{2,3}$ Divisi Bedah Saraf Bagian Bedah Fakultas Kedokteran Universitas Sam Ratulangi - RSUP \\ Prof. Dr. R. D. Kandou, Manado, Indonesia \\ ${ }^{4,5}$ Divisi Bedah Plastik Rekonstruksi dan Estetik Bagian Bedah Fakultas Kedokteran \\ Universitas Sam Ratulangi - RSUP. Prof. Dr. R. D. Kandou, Manado, Indonesia \\ ${ }^{6}$ Epidemiologi dan Biostatistik Fakultas Kesehatan Masyarakat Universitas Sam Ratulangi, \\ Manado, Indonesia
}

\begin{abstract}
Patients with end-stage glioblastoma multiforme (GBM) that cannot be operated or treated with chemotheraphy and radiotheraphy have increased clinical complaints, thus affecting the patients' quality of lifes (QoL). Hyperbaric oxygen therapy (HBOT) could alters hypoxic condition in tumor tissue with a different cascade from wound healing process. This study was aimed to assess whether the QoL of end-stage GBM patients could improve with the administration of HBOT assessed by decreased clinical complaints based on NANO score. The study was carried out at the Surgery Department of Prof. Dr. R. D. Kandou Hospital Manado, using pre and posttrial design. Each sample was assessed for the NANO score before HBOT, after one time, three times, five times, and 10 times of HBOT. The results showed that there was a change in the NANO score before and after 10 times of HBOT. The decrease in the NANO score occurred more quickly after the therapy. In the last two measurements, the NANO score according to the RVC model decreased from one to two units. The decreased NANO score occurred quite regularly with variations in the score that changed from time to time. In conclusion, HBOT can improve the QoL of patients with end-stage GBM and reduce the NANO score which is an assessment of clinical complaints of the patients.
\end{abstract}

Keywords: glioblastoma multiforme; hyperbaric oxygen therapy; NANO score

\begin{abstract}
Abstrak: Penderita glioblastoma multiforme (GBM) stadium akhir yang tidak dapat dilakukan operasi, kemoterapi dan radioterapi memiliki keluhan klinis yang semakin meningkat sehingga memengaruhi kualitas hidup. Terapi oksigen hiperbarik (TOHB) dapat mengubah kondisi hipoksia pada jaringan tumor dengan kaskade yang berbeda dari proses penyembuhan luka. Penelitian ini bertujuan untuk menilai apakah kualitas hidup pasien GBM stadium akhir dapat membaik dengan pemberian TOHB, dinilai dengan menurunnya keluhan klinis berdasarkan NANO score. Penelitian dilakukan di Bagian Bedah RSUP Prof. Dr. R. D. Kandou Manado, dengan menggunakan pre and posttrial design. Pada setiap sampel dilakukan penilaian NANO score sebelum TOHB, setelah satu kali, tiga kali, lima kali, dan 10 kali TOHB. Hasil penelitian mendapatkan adanya perubahan NANO score sebelum TOHB dan setelah 10 kali TOHB. Penurunan NANO score berlangsung lebih cepat pasca terapi tersebut. Dalam dua pengukuran terakhir, NANO score menurut model RVC turun dari satu hingga dua satuan. Pada grafik, hasil penurunan NANO score terjadi cukup beraturan dengan variasi score yang berubah dari waktu ke waktu. Simpulan penelitian ini ialah TOHB dapat meningkatkan kualitas hidup penderita GBM stadium akhir dan menurunkan NANO score yang menjadi penilainan keluhan klinis penderita. Kata kunci: glioblastoma multiforme; terapi oksigen hiperbarik; NANO score
\end{abstract}




\section{PENDAHULUAN}

Glioblastoma multiforme (GBM) merupakan tumor ganas primer pada susunan saraf pusat yang paling sering dijumpai di seluruh dunia. ${ }^{1-3}$ Kejadian GBM mencakup lebih $51 \%$ dari seluruh glioma. Dalam klasifikasi World Health Organization (WHO), GBM merupakan glioma derajat IV (high grade), yaitu derajat paling ganas serta memiliki prognosis paling buruk, ${ }^{1-3}$ termasuk pasien yang telah dilakukan reseksi lengkap disertai radioterapi dan kemoterapi. Walaupun gejala awal penderita GBM tidak spesifik, serta gejala klinis dan histologik GBM serupa satu dengan yang lain, namun secara genetik GBM merupakan tumor yang heterogen. ${ }^{1,4}$

Pada GBM terjadi kondisi hipoksia yang merupakan salah satu bagian penting dari perkembangan tumor dan resistensi terapeutik karena sel-sel tumor dapat mengaktifkan molekul adaptif yang memfasilitasi perkembangan GBM. ${ }^{4-6}$

Diagnosis GBM dapat dilakukan dengan magnetic resonance imaging (MRI), sedangkan pengobatan GBM dapat dilakukan dengan operasi, kemoterapi, dan radioterapi. Beberapa negara berkembang, seperti Jepang, telah menggunakan terapi oksigen hiperbarik (TOHB) untuk pengobatan pasien dengan GBM dan dilaporkan dapat memberikan hasil lebih baik dan memperbaiki kualitas hidup (quality of life/QoL) pasien menjadi lebih baik. ${ }^{5,7-9}$

Pada penelitian ini kualitas hidup pasien GBM stadium akhir dinilai dengan menggunakan NANO score. Penilaian NANO score merupakan suatu penilaian neurologik sederhana yang digunakan untuk mengevaluasi pasien saat kunjungan rutin. Pada NANO score terdapat sembilan domain, yaitu: gaya berjalan, kekuatan, upper extremity ataxia, sensasi, bidang visual, kekuatan wajah, bahasa, tingkat kesadaran, dan perilaku. ${ }^{10}$

\section{METODE PENELITIAN}

Penelitian ini menggunakan pre-post trial design, dengan populasi studi pasien tumor GBM stadium akhir yang berobat ke RSUP Prof. Dr. R. D. Kandou pada periode penelitian. Diagnosis GBM ditegakkan dengan gambaran MRI.

Kriteria inklusi pada penelitian ini ialah pasien yang tidak dapat dilakukan operasi, tidak dapat dilakukan pengobatan dengan kemoterapi dan radioterapi, telah menjalani pemeriksaan MRI, dan bersedia untuk berpartisipasi dalam penelitian dengan menandatangani surat persetujuan (informed consent) setelah mendapat keterangan tentang keuntungan dan risiko yang dapat terjadi selama penelitian. Kriteria eksklusi meliputi pasien yang disertai dengan keganasan atau kelainan hematologik, claustrophobia, barotrauma, sinusitis, pneumonia, dan COVID19. Keseluruhan penelitian dilakukan dengan berpegang teguh pada kaidah-kaidah etik penelitian subjek manusia yang berlaku di RSUP Prof. Dr. R. D. Kandou Manado.

Analisis data dilakukan dengan metode korelasi analisis menggunakan data hasil pemodelan dependensi via $R$-Vine Copula (RVC). Analisis kurva RVC dilakukan untuk melihat pergeseran kurva ke arah yang lebih kecil pada NANO score. Pengolahan data dan analisis statistik dilakukan sepenuhnya menggunakan software Statistik $\mathrm{R}$ versi 3.6.3.

Penelitian ini telah mendapat persetujuan dari Komisi Etik Penelitian Kesehatan RSUP Prof. Dr. R. D. Kandou Manado, dengan nomor keterangan layak etik yaitu No. 047/EC/KEPK-KANDOU/VI/2020.

\section{HASIL PENELITIAN}

Pada penelitian ini didapatkan dua orang pasien GBM stadium akhir yang memenuhi kriteria inklusi dan eksklusi. Kedua pasien tersebut berjenis kelamin laki-laki dan berusia di atas 50 tahun. Setiap pasien telah menjalani TOHB sebanyak 10 kali, dan dilakukan penilaian sebanyak lima kali.

Gambar 1 memperlihatkan grafik data NANO score di lima waktu pengukuran pada kedua subjek observasi dan mengindikasikan distribusi yang miring ke kanan, tetapi dengan gambar yang hampir sama mendekati bentuk distribusi normal. Hal ini menjadi alasan untuk memilih distribusi via $R$-vine copula (RVC).

Tabel 1 memperlihatkan uji statistik deskriptif kedua variabel berdasarkan data RVC. 


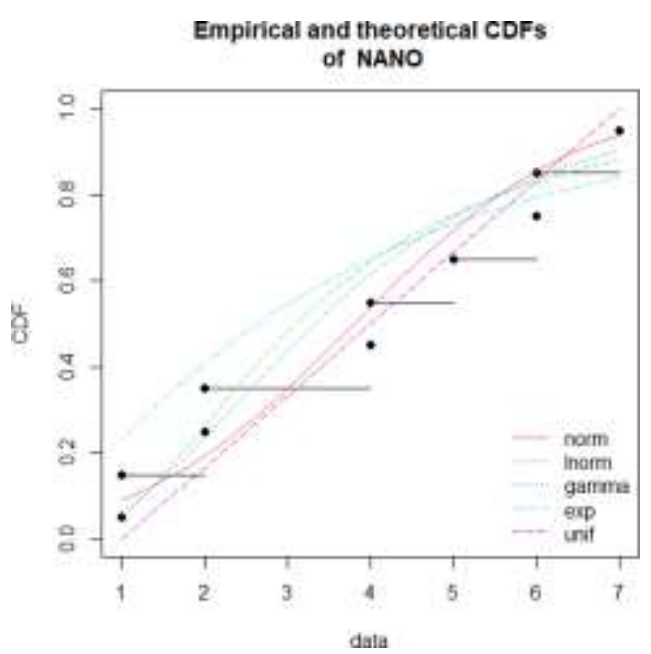

Gambar 1. Distribusi empirik NANO score dibandingkan dengan distribusi teoretik (normal, log-normal, gamma, eksponensial, dan uniform)

Nilai masing-masing tampak jelas turun berangsur di setiap pengukuran lanjutan. Setelah 10 hari pasca TOHB terlihat jelas penurunan NANO score pada setiap pengukuran, yang berlangsung lebih cepat setelah mendapatkan terapi 10 kali TOHB. Dalam dua pengukuran terakhir hari ke-5 dan ke-10, NANO score menurut model RVC turun dua satuan, sedangkan pada pengukuran pertama dan kedua hanya terjadi penurunan satu satuan.

Hasil penelitian mendapatkan perubahan NANO score pasca TOHB. Gambar 2 memberikan deskripsi visual mengenai perubahan nilai NANO score di setiap waktu pengukuran. Hasil pemodelan RVC pada kedua gambar tersebut dibandingkan juga dengan gambaran sesuai data awal. Hasil pengukuran NANO score data awal tidak terlihat jelas penurunan pada pengukuran, tetapi setelah dilakukan pemodelan RVC didapatkan hasil adanya penurunan.

Tabel 1. Distribusi NANO score selang waktu pengukuran sesuai data RVC

\begin{tabular}{lcc}
\hline $\begin{array}{c}\text { Waktu } \\
\text { pengukuran }\end{array}$ & \multicolumn{2}{c}{ NANO Score } \\
$\mathrm{M} \pm \mathrm{SD}$ & $\begin{array}{c}\text { Med } \\
(\mathrm{Q} 1-\mathrm{Q} 2)\end{array}$ \\
\hline Pra TOHB & $5,5 \pm 1,5$ & $5,4(4,4-6,6)$ \\
Hari 1 & $5,0 \pm 1,6$ & $4,7(3,8-5,9)$ \\
Hari 2 & $4,1 \pm 1,5$ & $3,9(3,1-4,9)$ \\
Hari 5 & $3,1 \pm 1,3$ & $3,0(2,1-3,8)$ \\
Hari 10 & $1,4 \pm 1,5$ & $1,3(0,4-2,2)$ \\
\hline
\end{tabular}

Ket: M mean, SD standar deviasi, Med median, $Q_{1}$ kuartil I, Q3 kuartil III, TOHB terapi oksigen hiperbarik

\section{BAHASAN}

Penelitian ini dilakukan terhadap pasien dengan tumor GBM yang dirawat di RSUP Prof. Dr. R. D. Kandou Manado dengan menggunakan pre post trial design. Dari sampel yang terkumpul selama tahun 2020, diperoleh dua pasien GBM stadium akhir dengan jenis kelamin laki-laki, dengan usia di atas 50 tahun. Pada masing-masing penilaian tampak jelas terjadi penurunan di setiap pengukuran lanjutan. Pada 10 hari pasca TOHB, penurunan NANO score pada setiap pengukuran berlangsung lebih cepat yang dapat dilihat pada dua pengukuran terakhir, NANO score menurut model RVC turun hingga dua satuan.

Terapi oksigen hiperbarik (TOHB) melepaskan $100 \%$ oxygen dengan tekanan yang lebih tinggi daripada tekanan atmosfir pada permukaan laut. ${ }^{11}$ Efek pemberian TOHB
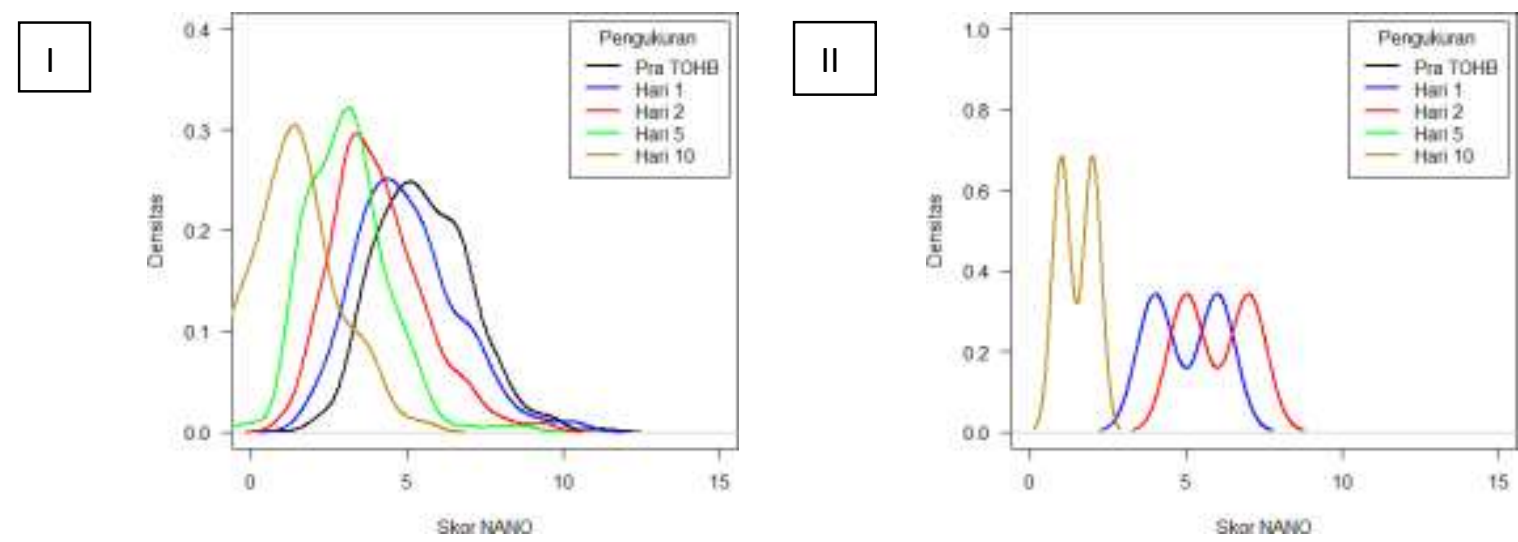

Gambar 2. Kurva densitas skor NANO sebelum dan beberapa waktu sesudah TOHB sesuai data $R$-Vine Copula (I) dan data awal (II) 
ialah meningkatkan tekanan parsial oksigen $\left(\mathrm{PO}_{2}\right)$ dalam darah dan oksigenasi jarringan. ${ }^{12}$ TOHB sendiri telah digunakan dalam pengobatan pasien GBM, dan memberikan luaran yang postif. ${ }^{11-14}$ Pada beberapa negeri berkembang TOHB digunakan untuk terapi pasien GBM bersamaan dengan kemoterapi maupun radioterapi, yang memberikan hasil tergolong baik pada pasien GBM. Beberapa teori menilai TOHB dapat meningkatkan jumlah oksigen yang terlarut dalam darah sehingga terdapat kekhawatiran yaitu terjadinya peningkatan oksigen dapat merangsang pertumbuhan tumor melalui reoksigenasi hipoksia sel tumor serta peningkatan angiogenesis seperti yang terjadi pada proses penyembuhan luka. Ternyata hal tersebut tidak terjadi pada mekanisme pertumbuhan tumor. ${ }^{15}$

Jaringan tumor yang hipoksik mengaktivasi faktor transkripsi yang mendukung kehidupan dan migrasi sel-sel tumor yang berakibat lanjut terjadinya resistensi terhadap radioterapi dan kemoterapi. Penelitian oleh Heddleston et al ${ }^{16}$ serta Osuka dan Van Meir ${ }^{17}$ melaporkan bahwa lingkungan mikro yang hipoksik mempromosi dan mempertahankan fenotip sel stem GBM yang mendukung terjadinya ketidak pekaan terhadap radioterapi dan kemoterapi. Selain itu jaringan sekeliling tumor mempunyai $\mathrm{PO}_{2}$ yang jelas lebih tinggi daripada jaringan dalam tumor; kondisi mikro demikian yang hipoksik sangat menguntungkan selsel tumor yang telah beradaptasi dengan $\mathrm{PO}_{2}$ rendah. ${ }^{18}$ Dengan demikian peningkatan oksigenasi tumor merupakan strategi untuk mengatasi efek yang tidak menguntungkan dari keadaan hipoksia sel-sel tumor pada penanganan $\mathrm{GMB},{ }^{19}$ yang mendukung penggunaan TOHB pada pasien GBM.

Pada penelitian ini digunakan NANO score sebagai penilaian terhadap kualitas hidup pasien GBM melalui sembilan domain neurologik. Penilaian NANO score pada penelitian ini dilakukan setelah pasien mulai diberikan TOHB, kemudian dinilai apakah terdapat perubahan NANO score setelah menjalani TOHB. Gambar 2 memperlihatkan bahwa hasil pengukuran skor NANO di data awal memberi kesan penu- runan. Disayangkan terdapatnya keterbatasan sampel sehingga data penelitian terbatas dan kurang bervariasinya penilaian yang membuat pengambilan simpulan tentang kecenderungan distribusi pasca TOHB cukup sulit. Sejumlah kurva tampak tumpang tindih. Pemodelan RVC sangat banyak membantu memperjelas perubahan yang terjadi pada penilaian NANO score. Sesuai data RVC, penurunan NANO score terjadi cukup beraturan dengan variasi score yang berubah dari waktu ke waktu.

Keterbatasan penelitian ini ialah penelitian dilaksanakan pada masa pandemi Covid-19 sehingga jumlah sampel yang diperoleh sangat terbatas.

\section{SIMPULAN}

Pemberian terapi oksigen hiperbarik pada pasien glioblastoma multiforme stadium akhir dapat meningkatkan kualitas hidup yang dinilai dengan penurunan NANO score.

\section{Konflik Kepentingan}

Penulis menyatakan bahwa tidak terdapat konflik kepentingan dalam studi ini.

\section{DAFTAR PUSTAKA}

1. Ostrom QT, Gittleman H, Liao P, Rouse C, Chen Y, Dowling J, et al. CBTRUS Statistical Report: Primary brain and central nervous system tumors diagnosed in the United States in 20072011. Neuro Oncol. 2014; 16 (Suppl 4): iv1-iv63. Doi: 10.1093/neuonc/nou223

2. Adamson C, Kanu OO, Mehta AI, Di CH, Lin NJ, Mattox AK. Glioblastoma multiforme: a review of where we have been and where we are going. Expert Opin Investig Drugs. 2009;18(8):1061-83. Doi: $10.1517 / 13543780903052764$.

3. Roth P, Regli L, Tonder M, Weller M. Tumorassociated edema in brain cancer patients: pathogenesis and management. Zurich: Department of Neurology, University Hospital Zurich, 2013.

4. Moulder JE, Rockwell S. Tumor hypoxia: its impact on cancer therapy. Cancer Metastasis Rev. 1987;5(4):313-41. Doi: 10.1007/BF00055376. 
5. Zhang X, Zhang W, Cao WD, Cheng G, Zhang YQ. Glioblastoma multiforme: Molecular characterization and current treatment strategy (Review). Exp Ther Med. 2012;3(1):9-14.

Doi: $10.3892 /$ etm. 2011.367

6. Knisely JPS, Rockwell S. Importance of hypoxia in the biology and treatment of brain tumors. Neuroimaging Clin $\mathrm{N}$ Am. 2002;12(4):525-36.

Doi: 10.1016/s1052-5149(02)00032-1.

7. Huang L, Boling W, Zhang JH. Hyperbaric oxygen therapy as adjunctive strategy in treatment of glioblastoma multiforme. Med Gas Res. 2018;8(1):24-8.

8. Stępień K, Ostrowski RP, Matyja E. Hyperbaric oxygen as an adjunctive therapy in treatment of malignancies, including braintumours. Med Oncol. 2016;33(9): 101. Doi: 10.1007/s12032-016-0814-0

9. Kohshi K, Beppu T, Tanaka K, Ogawa K, Inoue O, Kukita I, et al. Potential roles of hyperbaric oxygenation in the treatments of brain tumors. Undersea Hyperb Med. 2013;40(4):351-62.

10. Nayak L, DeAngelis LM, Brandes AA, Peereboom DM, Galanis A, Lin NU. The Neurologic Assessment in Neuro-Oncology (NANO) scale: a tool to assess neurologic function for integration into the Response Assessment in NeuroOncology (RANO) criteria. Neuro Oncol. 2017;19(5):625-35. Doi: $10.1093 /$ neuonc/nox029.

11. Gill AL, Bell CN. Hyperbaric oxygen:its uses, mechanisms of actions and outcomes.
QJM. 2004;97:385-95.

12. Huang L, Obenaus A. Hyperbaric oxygen therapy for traumatic brain injury. Med Gas Res. 2011;1:21

13. Hadley T, Song C, Wells L, Lehnhardt $\mathrm{J}$, Wells Rogers M, Anderson J, et al. Does hyperbaric oxygen therapy have the potential to improve salivary gland function in irradiated head and neck cancer patients? Med Gas Res. 2013;3:15.

14. Hu Q, Manaenko A, Matei N, Guo Z, Xu $\mathrm{T}$, Tang J, et al. Hyperbaric oxygen preconditioning: a reliable option for neuroprotection. Med Gas Res. 2016;6(1):2032.

15. Bhutani S, Vishwanath G. Hyperbaric oxygen and wound healing. Indian J Plast Surg. 2012;45(2):316-24.

16. Heddleston JM, Li Z, McLendon RE, Hjelmeland AB, Rich JN. The hypoxic microenvironment maintains glioblastoma stem cells and promotes reprogramming towards a cancer stem cell phenotype. Cell Cycle. 2009;8:3274-84.

17. Osuka S, Van Meir EG. Overcoming therapeutic resistance in glioblastoma: the way forward. J Clin Invest. 2017;127: 415-26

18. Beppu T, Kamada K, Yoshida Y, Arai H, Ogasawara K, Ogawa A. Change of oxygen pressure in glioblastoma tissue under various conditions. J Neurooncol. 2002;58:47-52.

19. Yetkin FZ, Mendelsohn D. Hypoxia imaging in brain tumors. Neuroimaging Clin $\mathrm{N}$ Am. 2002;12:537-52. 